\title{
Seaports, Urban Sustainability, and Paradigm Shift
}

\author{
Peter V. Hall
}

EAPORTS are big business; not just because of the valuable land, labor, and technology inputs they combine, but more so because of the role they play in global production and distribution systems. In his history of the first half-century of the ocean shipping container, Levinson argues that the container has been an integral piece in contemporary economic globalization. According to the United Nations, six and half billion metric tons of seaborne trade cargo was carried across the wharves of the world's seaports in 2004. These cargo movements do not simply transverse the waterfront; they move through sensitive marine ecosystems and along popular waterways, on city streets, through neighborhoods, and in shared rail corridors. Containerization and the rise of logistics have unleashed a fundamental change in the relationship among seaports, the localities that host them, and their associated cargo movements. These changes in seaports have important implications for the urban paradigm shift demanded by global climate and energy change.

The challenges of global climate and energy change demand that urban communities adapt to profound environmental and economic change, while shifting to a sustainable footing. Seaports will be on the front line of the adaptation process. The freight transportation and logistics systems in which seaports are embedded will confront a very different energy cost structure. Seaports will have to confront rising sea levels and more intense 
weather-related hazards. They will also face, and indeed already are in many places facing, increasing pressure to reform their own ecologically damaging practices. These include localized air pollution resulting from steamships and terminal activities, contributions to greenhouse gas emissions that occur along the entire transportation chain, and the damage that seaports inflict on coastal ecosystems through pollution and coastline transformation.

Paradoxically, at the same time as being implicated in environmental damage, seaports also have the potential of being important components of the shift to urban sustainability. Urban sustainability implies "improving the social and economic conditions of an increasingly urbanized population while preserving life systems and maintaining environmental quality." Short of the kind of dramatic and total disruption of trading systems contemplated by authors such as Kunstler, seaports may continue to play a vital role in the global economy because maritime transportation is cheaper, less polluting, and less energy intensive than air- and truck-based transportation alternatives. Switching to cleaner, more highly regulated ocean-based transport that is connected to predominantly rail-based distribution systems may be part of decoupling continued economic growth from increased transportation impacts.

For these reasons we might expect and hope for creative seaport and port-city adaptation in response to the climate and energy change considered in this special issue. How might this process of adaptation unfold? We cannot say with certainty how these changes will play out, but we can be sure that they will be shaped by the existing relationships between seaports and the cities that host them. With the intensification of containerization and the rise of the logistics industry over the last thirty years, urban seaports shifted from serving as gateways to their respective regions and associated hinterlands to functioning as logistics hubs that facilitate widely dispersed and accelerating global trade flows. This has brought a significant redistribution of costs and benefits among port workers, neighboring communities, local industries, and global manufacturers and distributors of goods located in Asia (e.g., Toyota), Europe (e.g., IKEA) and North America (e.g., WalMart). The resulting disconnection of seaports from host localities presents new challenges to the search for urban sustainability. In this essay I consider the technological, economic, and institutional dimensions of how global forces have confronted coastal localities through the process of disconnection. Lessons 
from the transformed relationship between coastal cities and their seaports can illuminate the dynamics of the urban paradigm shift.

\section{Port Technology and Infrastructure}

The essential characteristic of the modern ocean shipping container is that the cargo inside the box does not need to be handled directly at any stage while in transit. A variety of container-like systems were used in rail and ocean transportation in the early part of the twentieth century, including Seatrain Lines, which operated between Cuba and New York, and the White Pass and Yukon Route, which operated between Vancouver and Alaska. Malcolm MacLean, whose New Jersey to Houston service began in 1956, is widely credited with standardization and commercialization of the container as we know it today. Containers have become standardized as unwheeled boxes, varying in size from the standard twenty-foot equivalent unit (or TEU that is 20 feet by 8 feet by 8.5 feet) to as much as 53 feet long and 9.5 feet high. The standardization of the container has had profound consequences for transportation technology and infrastructure, since standard containers are all transportable on the same ships, trucks, and rail cars and may all be lifted by the same cranes and terminal yard equipment.

The container eliminated the need for a great deal of traditional port infrastructure. Finger piers with warehouses on the wharves that were designed to protect cargo in transit from the elements were no longer needed. Yet, in situ transformation of these waterfront facilities was the exception rather than the norm; typically, they were abandoned in favor of new locations. This is because pre-container port facilities were typically associated with river-front and downtown locations; these locations became increasingly undesirable because containerization is also associated with a drive for ever-larger ships. Larger ships require deeper water, and this requirement contributed to a migration of port facilities towards the mouths of rivers and to ocean-front locations. The downstream migration of port facilities is the most obvious physical manifestation of the disconnection between seaports and port cities.

Where migration could not occur, for example in the case of the Port of Durban which occupies a natural bay surrounded by the city, intense conflicts between the seaport and the city over land 
harbors do not exist, containerization has been associated with channel deepening (and widening) by dredging. Larger ships that can more efficiently load or discharge their cargo also require larger "surge" spaces; this requirement translates into wider marine terminals with space for stacking containers, handling equipment, and managing operations. These terminals are not safe for pedestrians, and they are hostile to the port-urban interface in a way previous marine terminals were not. The channel dredging and terminal construction required by containerization were frequently very controversial because public money was often used to finance projects that entailed the destruction and disruption of natural coastline ecosystems. In some cases, such as the case of the San Francisco Bay approach to the Port of Oakland, public opposition effectively delayed dredging.

Kagan

One metaphor that captures these changes is the notion that ports are less and less like a system of buckets, where each bucket has its own storage capacity, and more and more like valves at pipeline junctions, where flows are channelled along several paths, or accumulated into one big flow. The speed of the flow is, of course, determined by the narrowest part of the pipe. Since the 1990s, the road and rail connections to ports have received considerable attention. Inadequate landside transportation corridors have come to be regarded as major obstacles to further seaport expansion. In the United States, a series of federal research reports highlighted how crowded highways and at-grade crossings impede access to ocean terminals. In Canada, federal and provincial governments are investing heavily in infrastructure from ports in Vancouver and Prince Rupert all the way to Manitoba to expedite cargo movement between the Pacific coast and the North American midwest.

US DOT 1999 US DOT 2002

Government of Canada

\section{Port Economies}

The old industrial waterfront was visibly transformed as seaport facilities grew and became more isolated from their traditional urban locations. Often, when they departed, seaports left behind large areas containing under-serviced and derelict buildings, and sometimes environmental hazards. In time, some of these lands were converted into successful waterfront developments. However, it would be a mistake to ignore how delayed and painful this redevelopment was in many places and how little waterfront redevelopment often did for residents of the working 
Levine class neighborhoods that typically surrounded the traditional ports. In large measure, this is because the transformation of the old industrial waterfront in North America and western Europe was just one piece in the wider process of industrial restructuring. Manufacturing jobs migrated to the suburbs, to new industrial spaces, and to overseas locations; many warehousing and other cargorelated jobs have followed.

Campbell's analysis of the Oakland and San Francisco ports' restructuring confirms a story that is by now well known in most former general cargo (or break-bulk) ports. The Port of Oakland beat out San Francisco to become the Bay Area's major container port; most of the piers and warehouses in the Port of San Francisco have been converted for use in the service economy. Campbell also showed that much office-based port-related employment remained concentrated in the San Francisco downtown where propinquity to the finance, legal, and business service industries outweighed the benefits of re-locating to Oakland. In contrast, the citizens of Oakland discovered that winning the lion's share of container traffic was a hollow victory; container ports, unlike traditional break-bulk ports, which offered many employment opportunities in cargo handling, do not deliver the same direct benefits to their host locality. Worldwide, the number of people employed in seaports per unit of throughput has fallen dramatically, and in the developed world, many waterfront cargo-handling jobs were simply eliminated by the incredible efficiencies realized through containerization.

At the same time that local economic connections were changing and being loosened, seaports were extending their reach into larger trading hinterlands. This process has been especially profound in North America, where West Coast ports have been competing successfully for over 25 years to discharge cargo destined for East Coast consumers. The Ports of Los Angeles and Long Beach have been winners in this competition; it is estimated that today between 50 percent and 60 percent of imports through the ports have a destination outside of Southern California. It is important to understand that this competition takes place in a highly contestable market where, at the limit, the Southern California ports are not just in competition with Oakland and other West Coast ports, but indeed with major East and Gulf Coast ports.

As seaports competed with each other for the so-called discretionary cargo, that is cargo with an inland origin or destination not tied to a particular port, a new set of winners and 
losers emerged among the ports of the world. In his classic article, Hayuth predicted that economies of scale would result in a hierarchy of ports, with a small number of load centers and several feeder ports. The belief that relatively few ports would be able to achieve a dominant status allowed steamship lines to exploit the competition among ports to attract containerized cargo. As containerization gathered pace in the 1980s, steamship lines were increasingly able to pick and choose between seaports competing to provide the biggest cranes, the deepest channels, and the most favorable terminal leases. Indeed, by the early 1990s, Slack was describing ports as "pawns in a game". These economic dynamics further intensified the sense of disconnection; seaports no longer served their host cities and communities so much as they served steamship lines and their shippers.

The economic relationship between seaports and their host cities would surely not have changed as profoundly if it had not been accompanied by fundamental change in the organization of the global economy, in particular the rise of global value chains. Port managers have found themselves confronting increasingly powerful owners of cargo seeking to exercise greater control over logistics. One example of the shift from cargo carriers to cargo shippers is the formation of the West Coast Waterfront Coalition, which has represented the logistics interests of some of the largest cargo importers to the United States since 2000. In an article that has quickly become a classic in seaport literature, Robinson argues that these changes have fundamentally transformed how we should think about ports. He writes that "the role of ports and the way in which ports position themselves in the new business environments beyond 2001 must be defined within a paradigm of ports as elements in value-driven chain systems, not simply as places with particular, if complex, functions."

\section{Port Institutions and Organizations}

To fully comprehend the way in which power has shifted from port authorities to steamship lines, and subsequently to a new class of logistics actors, we need to consider the institutional and organizational changes associated with containerization. The infrastructural and economic disconnection of seaports from their host cities challenged the existing and often static, governance arrangements of seaports. 
The literature on seaport governance since the 1990s emphasizes two objectives. One stream emphasizes the need to develop comprehensive development strategies that take account of intermodal links and flexible port operations that facilitate regional

Heaver

Song

Notteboom and Winklemans World Bank

Brooks

Olson specialization. The second stream has concerned itself with port reform, devolution, deregulation, and privatization, an agenda promoted with some enthusiasm by the World Bank. Baird classifies ports according to which of the functions of regulation, land ownership, or operations are public responsibilities. While a few United Kingdom ports are fully private, relatively few of the world's major container ports are fully private in the sense that they are both owned and operated without any direct public regulatory oversight. Instead, port reform has resulted in a variety of new forms of port governance, almost all combining greater private-sector involvement in port operations with some measure of public-sector regulatory oversight. The trend towards disconnection might have been mitigated if city governments had taken up some of the regulatory oversight. However, this has typically not been the case; for example, in Canada, the directors of the largest port authorities are appointed by the federal transport minister.

The complexity and multiplicity of governance arrangements is visible within the decentralized system of public port authorities in the United States. There, most container ports are controlled by state and local government departments, agencies, or corporations, and government resources continue to subsidize port infrastructure. Yet, the private sector is able to exercise considerable control over individual terminal facilities. Beginning in the late 1970s, U.S. container ports, most notably the Port of Oakland, began experimenting with long-term leases and cargo guarantee schemes that sought to tie steamship lines to the expensive investments ports had made to provide the berths, cranes, yard equipment, and intermodal connections demanded by container carriers. Subsequent long-term leases were signed with steamship lines, converting many terminals from "common use" to "exclusive use" facilities.

It is important to view public-sector responses in the context of what else was going on in the container shipping industry during this time. In the competitive environment of containerization, steamship lines have sought to stabilize the market. To do so, they have engaged in a variety of horizontal integration strategies, including organizing liner conferences to set rates, co-operating through vessel- and slot-sharing agreements, and consolidating 
through formal mergers and acquisitions. They have also engaged in a series of vertical integration strategies where they acquire terminal operators, landside transportation providers, and logistics arms.

Of particular recent significance is the rise of the global terminal operator, "transnational corporations that have taken advantage of recent port reforms ... (and) ... now own/operate several terminals across a number of countries and continents." This class of port actor includes the state-owned Dubai Ports World and PSA International (formerly the Port of Singapore Authority) as well as the Hong Kong-based Hutchinson Port Holdings and U.S.-based Stevedoring Services of America. By 2002, these terminal operators accounted for over 40 percent of global container throughput. When combined with the terminal operating arms of ocean carriers, such as the APM Terminals owned by Maersk of Denmark, and NYK Line of Japan, which purchased Ceres Terminals in 2002, the share of global container throughput handled by private terminal operators now dwarfs that handled by public port authorities.

On the face of it, such vertical integration contains some hopeful signs for communities and environmentalists. For example, Everett highlights the dramatic increase in the modal share of rail in deregulated Australian ports. Likewise, integrated logistics chains are potential sites for the implementation of environmentally friendly measures such as re-usable packaging which can be more easily deployed in a tightly integrated logistics chain. However, with the shifting power from public to private terminal operators, any more sustainable approaches will be the by-product of profit-seeking behavior, not the conscious intent of some polity. With disconnection, the question remains: who will stop integrated freight services providers from continuing to impose congestion and pollution on communities hosting port facilities?

\section{Lessons from San Pedro Bay}

Despite their institutional, technological, and economic disconnection from the cities that host them, ultimate port users can only satisfy their desire for greater global mobility if they, or someone else, makes considerable fixed infrastructure investments in particular places. Under the right circumstances, this provides opportunities to otherwise marginal communities to secure 
mitigation for the costs of port activity and to capture some share of the benefits. Concerted action by public authorities can also help to find creative policy solutions to local environmental impacts. For example, although the Ports of Los Angeles and Long Beach have a long history of competition, they have also collaborated to solve shared problems, such as road congestion. In the early 1980s they began the infrastructural and institutional design work that was to become the Alameda Corridor. Opened in 2002, this twenty-mile long rail corridor links the ports with the major intercontinental rail yards to the east of downtown Los Angeles. It was built and is managed by a special-purpose agency, the Alameda Corridor Transportation Authority, and is financed through a combination of user fees and government funding.

Recent events in the twin mega-ports of San Pedro Bay provide further hopeful indications. In 2005, the ports handled over 14 million container units, and in so doing, they generated approximately 25 percent of the diesel air pollution in the

o'Brien region. Studies commissioned by the ports found that 90 percent of all sulfur oxides and 59 percent of diesel particulate matter came from ocean-going vessels. In the past five years, some level of agreement has emerged among local politicians, community activists, steamship lines and other freight carriers, cargo owners, organized labor, and port authorities about the need to address negative local environmental consequences of freight movement. This consensus was as hard-fought as it is fragile. It can be traced back to successful litigation by environmental and community groups and to considerable pressure by state lawmakers elected from port districts

In 2000, the Natural Resources Defense Council brought a lawsuit against the City and Port of Los Angeles for approving the China Shipping Line terminal without a complete environmental impact review or mitigation plan. The case was settled in 2004, with the Port agreeing to spend $\$ 50$ million over five years in mitigation, including the implementation of cold ironing which allows ships calling at the port to turn off their diesel engines and plug into the electricity grid. California state legislators, most notably Long Beach State Senator (and former State Assembly member and Long Beach City Councilor) Alan Lowenthal, have used both legislation and the threat thereof to spur action by regulators, port authorities, and industry. Lowenthal's legislation (California Assembly Bill 2650) restricted emissions resulting from trucks idling at terminal gates, by 
establishing and enforcing an appointments system. Terminal operators responded to this legislation and the prospect of even more regulation by creating the not-for-profit organization PierPass. The main activity of PierPass is the administration of OffPeak which provides a financial incentive for cargo owners to move cargo at night and on weekends.

The air quality improvement measures being proposed and adopted by officials in the ports of Long Beach and Los Angeles are to be lauded, as are the civic efforts that have prompted them. There is, of course, a long list of additional environmental mitigation measures that would be beneficial, some of which are already being implemented while others are being contemplated. These range from reinforcing established emissions monitoring and regulatory and incentive efforts at the regional scale to greater voluntary environmental improvements among port users. Global measures, such as giving the International Maritime Organization greater enforcement power over what happens at sea, or even emissions taxes that seek to internalize the true costs of transportation may also be effective in reducing overall environmental impacts. However, port cities cannot afford to wait for such concerted international actions that may come too late and that are unlikely to address the highly localized nature of many environmental impacts.

\section{Conclusion}

Port officials, community activists, and local politicians in southern California and elsewhere are constrained in their search for urban sustainability, or rather, in their initial movement towards contributing to that goal. That is so because the localities they represent are single links in global supply chains and can do little to control the environmental externalities resulting from cargo movement. Due to changes in transportation technology and infrastructure, pollution arising from port activity now extends deep into the ports' hinterlands. Changes in economic relations mean that increasingly the beneficiaries of port activities do not share the long-term interests of coastal communities. Finally, institutional disconnection implies that public port authorities find themselves operating in jurisdictions that are mismatched to the regional and global scale of the problems they seek to address and possess weak policy levers compared to increasingly powerful port tenants and cargo shippers. 
Just as seaports were on the front lines of urban change in the containerization paradigm shift, they are also likely to be on the front lines of the changes demanded by global climate and energy change. The question for communities in port cities such as Los Angeles is whether the transport functions of global trade can be made compatible with urban sustainability. This will involve adapting transportation infrastructure and using new technologies that reduce environmental damage, such as the greater use of on-dock rail systems. It will involve changing economic relationships, such as forgoing handling cargo that for ecological reasons should be handled elsewhere. And, it will involve institutional arrangements that provide localities with the power to enact and enforce these measures. Each of these tasks has been made more difficult by the current disconnection of seaports from their host localities.

And, the fact remains that even these measures may not be enough. Throughout this article we have been reminded that wider global dynamics lie behind the changes in the maritime shipping industry that have precipitated change in port cities. Container carriers and logisticians found their calling, so to speak, in a larger system of economic globalization which pursues the acceleration of goods movement at the same time as it seeks to reduce the cost of that movement. The technological, economic, and institutional disconnection described above is an urban manifestation of the wider paradigm shift in global economic relationships that began in the 1970s and intensified through the 1990s. Increasing, and at times apparently unconstrained, global trade has been facilitated by containerization and the rise of logistics, which in turn have fundamentally reconfigured the relationship between seaports and their host cities. Port-city disconnection would have not have unfolded as it did had powerful actors not been motivated by these wider goals.

For these reasons, we need to approach paradigm change as systemic and inter-connected, in the same way that urban sustainability needs to be understood as the integration of disparate elements and objectives to advance prospects for a common future. The question for port cities contemplating the adaptations that will be demanded by global climate and energy changes thus cannot stop with the search for port technologies, economies, and institutions that only mitigate the local costs of port-related activities. While such efforts will be necessary, a truly sustainable reconnection will require articulating a social and economic rationale for global trade in which transport functions can be 
reconciled with global energy and climate capacity. If seaports and port cities cannot articulate a vision which is compatible with the bottom line ecological requirements of urban sustainability, then they may be poised to enter another cycle of disconnection; instead of rotting wooden piers, this time the waterfront landscape will be littered with rusting cranes.

\section{Acknowledgments}

The author wants to thank the organizers and participants in the Workshop on Climate and Energy Challenges as Potential Triggers of Urban Paradigm Change, held in Vancouver on June 24, 2006. Thanks especially to Anthony Perl for his valuable comments on earlier drafts of this paper, as well as the anonymous reviewers. The usual disclaimers apply. 


\section{Bibliography}

A. Baird, "Privatization of Trust Ports in the United Kingdom: Review and Analysis of the First Sales," Transport Policy 2:2 (1995) 135-143.

M. Brooks, "The Governance Structure of Ports," Review of Network Economics 3:2 (2004) 68-183.

S. Campbell, "Increasing Trade, Declining Port Cities: Port Containerization and the Regional Diffusion of Economic Benefits," in H. Noponen, J. Graham, and A. Markusen, eds., Trading Industries, Trading Regions: International Trade, American Industry, and Regional Economic Development (New York: Guildford, 1993).

K. Corbert, "Double or Nothing: the Big Stakes of Hub Ports," The Journal of Urban Technology 3:2 (1996) 1-10.

CUPR, Towards a Comprehensive Geographical Perspective on Urban Sustainability: Final Report of the 1998 National Science Foundation Workshop on Urban Sustainability (New Brunswick, N.J.: Rutgers University Center for Urban Policy Research, 2000).

P. Dicken, Global Shift: Reshaping the Global Economic Map in the 21st Century, 4th Edition (New York: Guildford, 2003).

S. Everett, "Deregulation, Competitive Pressures, and the Emergence of Intermodalism," Australian Journal of Public Administration 61:3 (2002) 19-26.

R. Gilbert, "Globalization, Transport, and the Environment," paper prepared for the meeting of the OECD Environment Directorate Working Group on Transport (Paris, January $30-31,2006$ ).

Government of Canada, Canada's Asia-Pacific Gateway and Corridor Initiative (Ottawa: Government of Canada, 2006).

P. Hall, "Regional Institutional Convergence? Reflections from the Baltimore Waterfront," Economic Geography 79:4 (2003) 347-363.

P. Hall and G. Robbins, "Which Link, Which Chain? Inserting Durban into Global Automotive Supply Chains," in J. Wang, D. Olivier, T. Notteboom, and B. Slack, eds., Ports, Cities and Global Supply Chains (Aldershot: Ashgate, 2007).

D. Harvey, The Limits to Capital (Oxford: Blackwell, 1982).

J. Haveman and D. Hummels, California's Global Gateways: Trends and Issues (San Francisco: Public Policy Institute of California, 2004).

Y. Hayuth, "Containerization and the Load Center Concept," Economic Geography 57:2 (1981) 160-176. 
T. Heaver, "The Implications of Increased Competition for Port Policy and Management," Journal of Maritime Policy and Management 22:2 (1995) 125-133.

A. Helling and T. Poister, "U.S. Maritime Ports: Trends, Policy Implications, and Research Needs," Economic Development Quarterly 14:3 (2000) 300-317.

B. Hoyle, D. Pinder, and M. Husain, eds., Revitalising the Waterfront: International Dimensions of Dockland Redevelopment (London: Bellhaven, 1988).

R. Kagan, The Dredging Dilemma: How Not to Balance Economic Development and Environmental Protection, Working Paper 90-3 (Berkeley: Institute of Governmental studies, University of California at Berkeley, 1990).

J. Kunstler, The Long Emergency: Surviving the Converging Catastrophes of the Twenty-First Century (New York: Atlantic Monthly Press, 2005).

M. Levine, "Downtown Redevelopment as an Urban Growth Strategy: A Critical Appraisal of the Baltimore Renaissance," Journal of Urban Affairs 9:2 (1987) $103-123$

M. Levinson, The Box: How the Shipping Container Made the World Smaller and the World Economy Bigger (Princeton: Princeton University Press, 2006).

T. Notteboom and W. Winkelmans, "Structural Changes in Logistics: How Do Port Authorities Face the Challenge?" Maritime Policy and Management 28:1 (2001) $71-89$.

T. O'Brien, "Quality of Life and Port Operations: Challenges, Successes, and the Future," paper presented at the Sixth Annual CITT State of the Trade and Transportation Industry Town Hall Meeting (Long Beach, March 24, 2004).

D. Olivier and B. Slack, "Rethinking the Port," Environment and Planning A 38:8 (2006) 1409-1427. Quotation from page 1410.

D. Olson, "Public Port Accountability: A Framework for Evaluation," in M. Hershman, ed., Urban Ports and Harbor Development (New York: Taylor \& Francis, 1988).

A. Perl, New Departures: Rethinking Rail Passenger Policy in the Twenty-First Century (Lexington: The University Press of Kentucky, 2002).

PierPass, Official Homepage of PierPass (2006) < http://www.PierPASS.org/> Accessed October 15, 2006.

POLA and POLB, San Pedro Bay Ports Clean-Air Action Plan Technical Report: Draft (Los Angeles: Port of Los Angeles and Port of Long Beach, 2006) $<$ http://www.portoflosangeles.org/DOC/REPORT_Clean_Air_Tech.pdf $>$ Accessed October 17, 2006. 
R. Robinson, "Ports as Elements in Value-Driven Chain Systems: The New Paradigm," Maritime Policy and Management 29:3 (2002) 241-255. Quotation from page 252 .

J. Rodrigue, B. Slack, and C. Comtois, "Green Logistics," in A. Brewer, K. Button, and D Hensher, eds., The Handbook of Logistics and Supply-Chain Management, Handbooks in Transport \#2 (London: Pergamon/Elsevier, 2001).

B. Slack, "Pawns in the Game: Ports in a Global Transportation System," Growth and Change 24:4 (1993) 579-88.

B. Slack, C. Comtois, and R. McCalla, "Strategic Alliances in the Container Shipping Industry: A Global Perspective," Maritime Policy and Management 29:1 (2002) $65-76$.

D. Song, "Port Co-opetition in Concept and Practice," Maritime Policy \& Management 30:1 (2003) 29-44.

D. Stead and D. Banister, "Influencing Mobility outside Transport Policy," Innovation 14:4 (2001) 315-330.

UNCTAD, Review of Maritime Transport 2005 (Geneva: United Nations Conference on Trade and Development, 2005).

United States Department of Transportation (US DOT), An Assessment of the US Marine Transportation System: A Report to Congress (Washington, D.C.: U.S. Department of Transportation Maritime Administration, 1999).

United States Department of Transportation (US DOT), Intermodal Access to US Ports: Report on Survey Findings (Washington, D.C.: U.S. Department of Transport Maritime Administration, 2002).

World Bank, World Bank Port Reform Toolkit, 2nd Edition (Washington, D.C.: The World Bank Group, 2001) <http://www.ppiaf.org/Port/toolkit.html> Accessed April 18, 2007. 